\section{Butt clean up campaigns: wolves in sheep's clothing?}

\section{Simon Chapman}

\section{The best way to reduce cigarefte butt littering is to reduce cigarefte smoking}

t 2005, matches and lighters were struck under an estimated 5.494 trillion cigarettes consumed by the world's 1.3 billion smokers. The great majority of their non-biodegradable butts are thrown on the ground. Butts are easily the single most common form of litter, with one analysis showing they constitute $39 \%$ by weight of all litter. ${ }^{1}$ For many smokers, the world is their ashtray.

\section{BUTT LITTERING TRUST}

There is growing concern about this form of unsightly and dangerous ${ }^{2}$ pollution. Google shows 63500 hits for "cigarette butt" and "litter" and the international tobacco industry has got a nasty lungful of this new ill-wind and may be coming soon with a big environmentally friendly smile to run a publicity campaign near you. In Australia, British American Tobacco has set up the Butt Littering Trust, with \$A2.8 million (US\$2.089 million, $€ 1.619$ million) allocated over four years. Philip Morris has spent \$A331 775 (US\$247 454, €191 833) on butt litter reduction in one Australian state. ${ }^{1}$ Cheery staff hand thoughtful smokers a little film canister to store their butts, and suburbs get awards for running local awareness campaigns. The Butt Littering Trust website gushes that by April 2006, three years after the programme commenced, 12000 Australians smokers have "signed the pledge" to not discard butts. This leaves around 2880000 who haven't signed and provides insight into a recent government assessment of these campaigns which "have not translated into widespread reduction of cigarette butt litter. The impact of current activities funded by cigarette manufacturers is clearly unsatisfactory."

The Butt Littering Trust is wholly supported by British American Tobacco (BAT), whose representatives sit on its board. The Trust's chairman is adamant that BAT plays no role in shaping the strategies and goals of reducing butt litter. So why then is the Trust equally adamant that it will limit its efforts to education and not join with other organisations to try and reduce the number of cigarettes being smoked, and then available to be discarded as litter?

All anti-litter campaigns openly embrace three broad strategies: reducing use, recycling and education to "do the right thing". Serious anti-litter organisations campaign to reduce packaging such as plastic bags, and lobby for bottle deposit legislation and tougher fines for littering. The Butt Littering Trust deliberately limits itself to education. Imagine how seriously the community would regard a plastic bas manufacturer setting up a Trust to educate shoppers not to discard bags, while lobbying hard to oppose any reduction in bag use. This is exactly analogous to what BAT is doing through the Trust. Grantees are warned that all communication with the public must adhere to the Trust's key messages, with all public statements being vetted for "consistency in messages". Don't even think about urging smokers to quit.

\section{OPPOSING OUTSIDE SMOKING BAN}

But it gets worse. Along with long-time tobacco industry ally the Australian Hotels Association, the Trust has recently opposed moves by Newcastle City Council to ban smoking at outside al fresco restaurant and café tables where many non-smokers have complained that they must sit cheek-by-jowl with smokers who are not permitted to smoke indoors. ${ }^{3}$ The Trust argues that smoking bans have caused smokers to move outdoors, where many discard their butts.

The wider view is that reduced smoking opportunities mean reduced smoking. ${ }^{4}$ When smokers cannot smoke in particular settings, they smoke fewer cigarettes. When fewer cigarettes are smoked, fewer cigarettes are available to be dropped on the ground and less disease is caused as well.

Reducing the prevalence of smoking would do more than any other strategy to reduce butt pollution. In the 1960s, nearly $70 \%$ of Australian men and around $30 \%$ of women smoked. Today, just over $17 \%$ smoke everyday. ${ }^{5}$ The only people who discard butts are smokers. Thirty per cent of all Australian adults used to discard butts and now never do, because they are ex-smokers. Effective tobacco control reduces both the number of smokers in the community and the amount of cigarettes smoked per day by continuing smokers. It controls butt littering at source, because it reduces the number of "sources" who each have on average some 6200 butts to dispose of each year.

Trying to persuade smokers to be more considerate, and law enforcement of anti-littering provisions, are two important components of butt reduction efforts. But they are minor, band-aid contributors to the problem at large. BAT has a naked conflict of interest in addressing the litter question. The Butt Littering Trust directors are either willing or naively unwitting allies in this sham. Tobacco control advocates in Australia are now working with some success with local government authorities to alert them to the broader agenda of tobacco industry sponsored anti-litter campaigns.

Tobacco Control 2006; 15:273. doi: 10.1136/tc.2006.017590

Correspondence to: Professor Simon Chapman, School of Public Health, University of Sydney, Building A 27, Sydney, NSW 2006, Australia; simonchapman@health.usyd.edu.au

\section{REFERENCES}

EPR Expert Reference Group. Report on the implementation of the New South Wales extended producer responsibility priority statement 2004, Department of Environment and Conservation, New South Wales. http://www.resource.nsw. gov.au/data/epr/EPR2004-ERG\%20reportFinal.pdf.

2 Chapman S, Balmain A. Time to legislate for firesafe cigarettes in Australia. Med J Aust 2004:181:292-3.

3 Vallejo J. No smoking idea no-go for council. Daily Telegraph (Sydney), 2006;May 5, 15.

4 Chapman S, Borland R, Scollo M, et al. The impact of smoke-free workplaces on declining cigarette consumption in Australia and the United States. Am J Public Health 1999;89:1018-23

5 Australian Institute of Health and Welfare. 2004 National Drug Strategy Household Survey: detailed findings. Canberra: AlHW, 2005, Report No.16. http://www.aihw.gov.au/publications/ phe/ndshsdf04/ndshsdf04.pdf. 